Rhetoric" contrasted the stagnant (in his view) field of labor studies with the more theoretically exciting field of women's studies which has been more open to poststructuralist social and cultural theory. He called for a new figuration of labor studies that would 1) abandon the notion of production and exchange as a distinct realm of social relations separate from politics and culture; 2 ) equally abandon the fundamental paradigm of the economy as exclusively material (it is also cultural and symbolic); and 3) move beyond old disciplinary boundaries. Christopher Johnson echoed Sewell's plea in "Economic Change, Class Experience and Consciousness: Some Questions After Reading Habermas." Labor historians, argued Johnson, need to approach societies as life-worlds - through the meanings people give to their activities - and in terms of the structures and systems that give them shape. Subjectivity and intentionality are important elements of the constructed world - at least as important as the structures and systems to which they give meaning. Johnson suggested that Habermas provides a lifeline to rescue labor history from its current doldrums.

In fact, current work by U.S. historians in French labor history-especially women's history - has already begun to embody these ideas. Attention to discourses, to representations, and to the assignment of cultural meanings has already begun to inform the work of social historians as they attempt to expand their understanding of the world of workers and of labor movements. These concerns with theory and interdisciplinarity, however, may be particular to the work of historians on this side of the Atlantic. As Michelle Perrot pointed out in her comments, the debates about the use of post-structuralist social and cultural theory in historical analysis that have occurred here are absent in France, probably because the French have distanced themselves from Marxism and because French intellectuals and historians have been much less interested in post-structuralism than their American counterparts.

\title{
Conflict and Cooperation: Comparative Research on the East European Migratory Experience, 1880s-1930s
}

\author{
Donna Gabaccia \\ Mercy College
}

In late April 1990, the University of Bremen's Volkswagen-sponsored project "Conflict and Cooperation: Comparative Research on the East European Migratory Experience, 1880s-1930s" brought together more than fifty scholars from twelve nations in a final conference. Like all the Bremen projects under the direction of Dirk Hoerder, this undertaking began with the premise that labor migrations created multiethnic working classes in industrial centers everywhere; 
Bremen has never studied labor migration or class formation as exclusive subtopics of U.S. history. This "Atlantic perspective" (as Hoerder puts it) explains both the multilingual cast of participants and the wide-ranging focus of the conference.

The five-day gathering highlighted research completed by project members, but its main purpose was to identify broader themes in the study of labor migrants on both sides of the Atlantic. Like all Bremen initiatives, the East Europe project was collaborative, involving U.S., German, Hungarian, Polish, Czech, Croatian, Slovak, and Slovenian scholars and institutions. Working together both in Europe and on research trips to Cleveland, collaborators studied the migration and interaction of East European migrants in Budapest and in Cleveland-attractive destinations for the relatively under-studied East European labor migrants of the turn of the century.

The conference was organized loosely around three major themes: the development of peasant and artisan consciousness in the lands of origin; the transfer of political and social consciousness to the new homelands; and the impact of European migrants on the labor movements of the new homelands. Less wellintegrated, but of considerable interest nevertheless, were sessions on women in the migration process, transit migration through German ports, and the impact of migration on the lands of origin. Papers had been circulated prior to the conference, so most sessions resulted in lively discussion.

Predictably, differences arose in discussions of all three themes. Some originated in disciplinary concerns, some in ethnic or national ones. Still others seemed more a consequence of what might be called differing academic or generational cultures. Disciplinary differences were particularly obvious in discussions of the peasants and artisans of migrants' rural homelands. Ethnographic accounts of peasant life more often emphasized peasant conservatism, while historians uncovered evidence of primitive rebellion and flourishing pockets of agrarian socialism by the 1890 s. It remains a daunting challenge to integrate these conflicting interpretations with accounts either by demographers or by historians who trace the development of national labor movements through institutions. While we have moved a long way beyond earlier interpretations of rural people separated from the flow of history by "the idiocy of rural life," we still lack a coherent interpretation of the agrarian origins of most urban and industrial workers of the nineteenth and twentieth centuries.

The ethnic tensions in the German, Russian, and Austro-Hungarian empires reemerged persistently in matters both large and small. Tellingly, most Eastern Europeans refer to national, not ethnic, differences. There was an implicit tension between the comparative ambitions of the conference and the current desire of many Eastern European scholars (especially those from multiethnic nations like Czechoslovakia and Hungary where ethnicity has been denied or repressed) to tell the histories of particular ethnic groups. Some scholars treated ethnicity as a given, emphasizing the particularism of group historical experience and the centrality of ethnicity to the organization of oppositional movements. For these scholars, the conference offered an opportunity to consider how ethnic conscious- 
ness formed in the Old World shaped behavior and action in the New. Other scholars, however, especially the French and U.S. labor historians, emphasized ethnicity's situational character and the extent to which individuals create ethnicity as one element of their working-class identity. These scholars were more interested in the interaction of workers of many ethnic backgrounds, especially in their new urban homelands. This disagreement never evolved - as it could have and sometimes has - into a simplistic disagreement over ethnicity versus class. But the tension between the approaches is far from resolution.

Recent changes in Europe provide an interesting backdrop to historical debates like these. Although the official language of the conference was English, many East European participants were more comfortable with German-another reminder of the influence of imperial pasts. Political change in the East allowed at least one participant to travel to a foreign conference for the first time. It also fueled lively and sometimes passionately contentious and multilingual explorations of past and present.

Overall, the wide-ranging and comparative aims of the conference brought suggestive, but not conclusive, results. By aiming so broadly, a number of important details remained vague. Many conference participants would have liked to hear more from the project researchers about the results of their research in Cleveland and Budapest. Even more, many wanted to learn more of the Bremen project's experience with collaborative research. For students of multiethnic working classes, collaborative research may be the only way to pursue comparison and synthesis without abandoning the full range of sources in many languages and countries. When queried, one project researcher noted, rather ruefully, that " "Conflict and Cooperation' said it all." Were Bremen researchers influenced by earlier collaborative efforts like the Philadelphia Social History Project? Did the Bremen research process replicate the tangled interethnic relations of workers in Cleveland and Budapest? Obviously, this was sensitive territory, where personality, ethnicity, and politics intertwined quite palpably with scholarship. If the Bremen group is to provide a model for others - as I believe it could - the research process itself, with all its warts, needs further explication and perhaps some outright analysis.

\title{
Perspectives on Labor History: The Wisconsin School and Beyond
}

\author{
Shelton Stromquist \\ University of Iowa
}

One hundred and seventy scholars and other persons interested in the current state of American labor history gathered March 9-10, 1990, for a conference at the State Historical Society of Wisconsin. The conference was organized as a joint venture 